\title{
Experimental infection of Atlantic salmon (Salmo salar) with marine Eubothrium sp. (Cestoda: Pseudophyllidea): observations on the life cycle, aspects of development and growth of the parasite
}

\author{
Monica Saksvik $^{1}$, Are Nylund ${ }^{1}$, Frank Nilsen ${ }^{2}$ and Kjartan Hodneland ${ }^{1}$ \\ ${ }^{1}$ Department of Fisheries and Marine Biology, University of Bergen, HiB, N-5020 Bergen, Norway; \\ ${ }^{2}$ Institute of Marine Research, Department of Aquaculture, P.O. BOX 1870, N-5817 Bergen, Norway
}

Key words: Cestoda, growth, Eubothrium sp., experimental infection, crowding effect, Salmo salar, life cycle, Acartia tonsa

\begin{abstract}
The life cycle of marine Eubothrium sp. (Cestoda: Pseudophyllidea), from Atlantic salmon (Salmo salar L.) was experimentally completed in one year and included only one intermediate host (Acartia tonsa Dana) (Copepoda: Calanoida). Adult cestodes were collected from farmed salmon, and ripe eggs released by the cestodes were fed to Acartia tonsa. Ingested eggs hatched in the gut and the larvae developed in the haemocoel of the copepod for 15 days at $16^{\circ} \mathrm{C}$. A total of 170 seawaterreared salmon were exposed to infected copepods and the total prevalence of Eubothrium sp. in the salmon after infection was $95.3 \%$, with a mean intensity of 15.0 (range 1-87). The infected salmon were kept in the laboratory where the growth of the cestodes was studied for eleven months. Mean length of the cestodes increased with time, but a large variation among the cestodes was observed. Growth and maturation of the cestodes were dependent on host size and the number of worms present in the intestine. No evidence of mortality of Eubothrium sp. was observed during the experimental period.
\end{abstract}

Eubothrium crassum (Bloch, 1779) is a widely distributed intestinal parasite of salmonids in Europe, North America and the former USSR (Wardle and McLeod 1952, Hoffman 1967, Kuperman 1978). This cestode has also been recorded from bream (Abramis brama), carp (Cyprinus carpio), perch (Perca fluviatilis), pike (Esox lucius) and rudd (Scardinius erythrophthalmus) (Kane 1966), but these observations are considered to be the result of accidental infections (Kennedy 1978a). Stickleback (Gasterosteus aculeatus) and ruffe (Gymnocephalus cernua) have been found to be infected with E. crassum and are regarded as paratenic hosts (Vik 1963, Wootten 1972). In addition, E. crassum has been reported from Coregonus spp. and several other hosts (Yamaguti 1959, Dogiel et al. 1961, Bykhovskaya-Pavlovskaya et al. 1964).

According to Kennedy (1978a), E. crassum is considered to consist of three races; a European freshwater race which infects Salmo trutta, S. salar and Oncorhynchus mykiss, an Atlantic marine race found in $S$. salar and $S$. trutta, and a third race found in Pacific marine Oncorhynchus spp. Bristow and Berland (1989) performed a preliminary study of allozymes which indicated that the freshwater race is genetically distinct from the marine race and they regarded E. crassum as consisting of two different species.

The life cycle of E. crassum in freshwater was considered by Rosen (1918) to consist of a copepod (commonly Cyclops spp.) as the first intermediate host, a fish (perch) as the second intermediate host, and trout
(S. trutta) as the final host. Vik (1963) showed that stickleback ( $G$. aculeatus) may serve as second intermediate host, or more likely as a transport host, and indicated that the copepod could infect the final host (trout) directly. Wootten (1972) and Mulcahy and Kennedy (1970) suggested that the life cycle of freshwater E. crassum involves only one intermediate host, a copepod. The intermediate host or hosts of marine Eubothrium sp. are poorly known, and information concerning its life cycle is lacking. Akhmerov (1962) suggested that only one intermediate host (a copepod) is necessary in the marine life cycle. Different species of copepods have been experimentally infected with eggs from marine Eubothrium sp., but only a single fish ( $S$. salar) has been successfully infected by ingesting copepods (Hodneland and Solberg 1995). The aim of the present study was to confirm the life cycle of marine Eubothrium sp., maintain a laboratory popula-tion of different life cycle stages of marine Eubothrium sp. in a large-scale experiment, and to study the growth of the cestode in the fish host.

\section{MATERIALS AND METHODS}

To complete the life cycle of Eubothrium sp. it was necessary to maintain the final host ( $S$. salar L.) and one intermediate host (a marine copepod) in the laboratory. Acartia tonsa Dana was chosen as experimental host since it is fairly easy to keep in culture and readily available. Cultures of A. tonsa required production of algae as food particles. 
Algae cultures. Laboratory strains of Rhodomonas baltica and Isochrysis galbana were cultivated at $16^{\circ} \mathrm{C}$ in 2 - or 5 -litre bottles and 10-litre bottles, respectively. The algae were maintained as continuous cultures in autoclaved filtered sea water $(0.2 \mu \mathrm{m}$ mesh $)$. The cultures were added $\mathrm{B} / 2$ nutrients (Walne 1970) at a ratio $1 \mathrm{ml} \mathrm{l}^{-1}$ every 2nd-3rd day. Isochrysis galbana was kept at a density of 2-3 $\times 10^{6}$ cells per $\mathrm{ml}$ and $R$. baltica at a density of $1-2 \times 10^{6}$ cells per $\mathrm{ml}$. The cultures were given continuous light and oxygen. Salinity of the sea water was $34.5 \pm 0.2 \%$.

Copepod culture. Copepod eggs were obtained from a laboratory culture of Acartia tonsa (Støttrup et al. 1986). The copepods were kept in 75-litre green cylinder-shaped PVC tanks with a transparent window $(50 \times 20 \mathrm{~cm})$ and plastic cover. Oxygen was added through the funnel-shaped bottom of the tanks. The copepods were kept at $16^{\circ} \mathrm{C}$ and given continuous light. They were fed daily with $200 \mathrm{ml}$. baltica and $200 \mathrm{ml}$ I. galbana. Every week, 10 litres of water were siphoned out from the bottom of the tanks and replaced with fresh filtered sea water $(0.2 \mu \mathrm{m}$ mesh). The $A$. tonsa cultures were maintained in 12 tanks and the concentration of copepods was 50-150 per litre including all stages.

Fish. Smolts of Salmo salar were purchased from the salmon producer Øyerhamn, in May 1995. When still in the freshwater phase, 30 fish were examined for metazoan intestinal parasites, and none were found to be infected. The smolts were transported to the Industrial Laboratory at Bergen High Technology Centre, transferred to sea water, and kept for 3 months prior to experimental infection with marine Eubothrium sp. The fish were kept at $9.5^{\circ} \mathrm{C}$ in covered circular green PVC tanks, with a diameter of $2 \mathrm{~m}$ and a volume of 20001 under the natural light regime for Bergen $\left(60^{\circ} 25^{\prime} \mathrm{N}, 5^{\circ} 20^{\prime} \mathrm{E}\right)$. Commercial food pellets (Red Royal; Skretting) were fed to the salmon every second day from automatic feeders and weight of food per fish was given at a factor of $1.2 \%$. Pellet size was initially $4 \mathrm{~mm}$ and was changed in January 1996 to $6 \mathrm{~mm}$. Sea water from $90 \mathrm{~m}$ was used $(34.5 \pm 0.2 \%)$. The water flow was regulated to ensure $80 \%$ oxygen saturation in the outlet. The fish were tagged individually with eye tags (Northwest Marine Technology, visible implant [V.I.] tag).

Infection procedure. To ascertain marine origin of Eubothrium sp., 30 farmed salmon were examined in freshwater phase in April 1994. In addition, 30 salmon were examined every third week after transfer to sea. Eubothrium sp. was not observed before June 1994, i.e. after nine weeks in the marine environment. In order to obtain cestode eggs, farmed $S$. salar from the same farm were examined for Eubothrium sp. at a salmon processing plant in July 1995. Intestines with Eubothrium sp. were brought to the laboratory, and the cestodes were examined for ripe eggs during a 36hour period. The intestines were kept at $4{ }^{\circ} \mathrm{C}$ prior to examination. The cestodes were removed from the intestine and transferred to Petri dishes with $1 \% \mathrm{NaCl}$ solution to induce egg release. Worms releasing ripe eggs were dissected to obtain as many eggs as possible. The eggs were treated with penicillin and streptomycin $\left(20 \mathrm{U} \mathrm{ml}^{-1}\right)$ and kept at $4^{\circ} \mathrm{C}$ for 12 hours prior to infection. The copepods were starved 24 hours prior to the infection and approximately 55 ripe eggs were given to each adult copepod in the tank. One batch of eggs was added each hour to the tanks during a period of 4 hours. Procercoids were allowed to develop for 15 days in the haemocoel of the copepod, as a preliminary study had indicated that this was sufficient time to make them infective to the fish (pers. obs.).

In August 1995, 170 salmon were intubated with infected copepods. The fish were starved 24 hours prior to all handling, i.e. tagging and challenge. The fish were measured for fork length and weight. At the time of infection, the salmon mean weight and length were $83 \pm 13 \mathrm{~g}$ (range $=48-115 \mathrm{~g}$ ) and 20.4 $\pm 0.4 \mathrm{~cm}$ (range $=18.1-22.5 \mathrm{~cm})$, respectively, and the mean c-factor was calculated to $0.97 \pm 0.03$ (range $=0.78-1.20$ ) . Each fish was intubated with approximately 60 infected copepods using a 1-ml syringe. Anaesthetic was not used during the infections of the fish. Following intubation some coughing and regurgitation of the copepods was observed. The infected fish were kept in the same tank as nonchallenged control fish.

In order to determine presence and growth of Eubothrium sp., samples of ten fish were collected in November, December, January and at the end of the experiment in July. In February 40 infected and 40 uninfected fish were removed from this experiment and challenged with infectious salmon anaemia virus (ISAV) and then starved for up to two months. The cestode number was recorded (further results from this experiment will not be presented here).

The live cestodes were fixed in hot $\left(80^{\circ} \mathrm{C}\right) 4 \%$ formaldehyde with pH 7.4 (Burt 1984) and were measured to the nearest $\mathrm{mm}$. At the end of the experiment, the wet weight of worm infrapopulation was measured from 90 fish and gravid worms with eggs were registered.

The use of ecological terms is in accordance with Margolis et al. (1982). The Atlantic marine race will be referred to as Eubothrium sp., and the freshwater race as E. crassum.

Statistics and formulae. The condition factor was calculated according to Fultons; $\mathrm{c}=100 \mathrm{wl}^{-3}, \mathrm{w}=$ weight $(\mathrm{g})$ and $1=$ length $(\mathrm{cm})$. A Kolmogorov-Smirnov two-sample test was used to determine if there was any mortality among the cestodes during the experimental period, i.e. if there were any changes in mean intensity of infection between the different samples. To examine whether data followed a normal distribution, a Kolmogorov-Smirnov test was performed. Multiple regression analysis was used to examine any correlation between fish size (length, weight and c-factor) and intensity of the cestodes. The same test was used to determine any correlation between fish weight and weight of worm infrapopulation. To determine any correlation between number of cestodes and cestode length in each fish, a Sperman rank test was applied. This test was also used to observe any relationship between fish weight and worm length. A MannWhitney U-test was used to examine possible differences between number of cestodes in fish with and without gravid cestodes. For analysing statistical differences between other groups, one-way ANOVA was performed. A Levene F-test was used to examine the homogeneity of variances. Logtransformation was applied prior to analyses to normalise the data when appropriate. All statistical analyses were performed in Statistica ${ }^{\mathbb{R}}$ version 5.0, and data were considered significant if $\mathrm{p}<0.05$. 


\section{RESULTS}

The Eubothrium sp. eggs were ingested by Acartia tonsa, and the hexacanth larvae hatched from the eggs, penetrated the intestine of the copepod and entered the haemocoel. The larvae developed several calcareous corpuscles and a cercomer in the haemocoel. After 15 days, the mean prevalence of Eubothrium sp. in the copepods in different tanks was $26.3 \%$ (range $=7-50$ ) and the total mean intensity was $1.1 \pm 0.24$ (range $=1-3$ ).

Prevalence, mean intensity and range of Eubothrium sp. infection in the salmon are given in Table 1. There was no significant difference in mean intensity between the different samples, and prevalence was stable during the experimental period. The cestodes were mainly observed in the pyloric caeca, but a few were found in the intestine. None of the control fish was infected with Eubothrium sp.

Mature, gravid cestodes were not observed until the last sample (July 1996), eleven months after infection. At this time, only 62 out of 1427 (4.3\%) of the cestodes examined contained eggs. Gravid/pregravid Eubothrium sp. were found in $40 \%$ of the infected fish, and the mean intensity was $1.7 \pm 0.8$ (range $=1-4$ ). The gravid/pre-gravid Eubothrium sp. were found in fish harbouring a significantly lower number of cestodes, and in fish with a significantly larger size compared with those fish without oviferous cestodes (Table 2). Mean infra-population weight of Eubothrium sp. in the fish showed no significant difference between those fish harbouring gravid cestodes and those without them.

The mean weight of the infected fish in July was 571 $\pm 168 \mathrm{~g}$ (range $=266-1175 \mathrm{~g}$ ) and mean infrapopulation weight of cestodes per fish was $5.7 \pm 2.5 \mathrm{~g}$ (range $=0.7$ $12.3 \mathrm{~g}$ ). At this point there was a significant positive correlation between fish weight and infrapopulation weight of Eubothrium sp. $\left(\mathrm{p}<0.05, \mathrm{r}_{\mathrm{s}}=0.60\right)$. There was also a significant positive correlation between the number of Eubothrium sp. and the infrapopulation weight of the cestodes $\left(\mathrm{p}<0.05, \mathrm{r}_{\mathrm{s}}=0.32\right)$.

The length of Eubothrium sp. varied within and between hosts (Table 3). The smallest cestodes were most frequent in fish harbouring the largest number of worms, and the largest cestodes were usually found in fish with few Eubothrium sp. Mean length and range of the cestodes increased with time. The length distribution showed a shift towards larger cestodes with time, but there were still cestodes smaller than $0.5 \mathrm{~cm}$ present in the fish at the end of the experiment (Fig. 1). The length of individual cestodes was negatively correlated with the number of worms present in the fish and positively correlated with fish size (Table 4).

\section{DISCUSSION}

Pseudophyllidean cestodes may have one or two intermediate hosts involved in their life cycles. Experimental infections have shown that in the life cycle of Bothriocephalus gregarius, B. claviceps, B. barbatus and Eubothrium salvelini only one intermediate host is essential and the final fish host can be infected from the copepod directly (Boyce 1974, Robert and Gabrion 1991, Morand et al. 1995, Scholz 1997). In fresh water, Vik (1963) observed that Eubothrium crassum was able to complete the life cycle in lakes where the only fish species present was Salmo trutta. It was therefore suggested that E. crassum could be transferred directly from a copepod intermediate host to the trout and develop from procercoid stage to adult in the trout intestine without the need of a second intermediate fish host as suggested by Rosen (1918). This tentative life cycle suggested by Vik (1963) was later supported by two separate studies. Wootten (1972) reported that rainbow trout (Oncorhynchus mykiss), which had no contact with any possible intermediate hosts except copepods, were infected with E. crassum. Mulcahy and Kennedy (1970) observed that salmon

Table 1. Occurrence of Eubothrium sp. in experimentally infected salmon.

\begin{tabular}{|l|c|c|c|c|c|c|}
\hline & November & December & January & April & July & Total \\
\hline Number of fish & 10 & 10 & 10 & 40 & 100 & 170 \\
Prevalence (\%) & 100 & 90 & 90 & 93 & 97 & 95 \\
Intensity, range & $1-21$ & $1-56$ & $3-21$ & $1-87$ & $1-78$ & $1-87$ \\
Intensity, mean & 11.2 & 17.8 & 10.1 & 14.0 & 15.9 & 15.0 \\
\hline
\end{tabular}

Table 2. Data on fish with and without gravid/pregravid Eubothrium sp. Values are given as mean $\pm 95 \%$ confidence level. Values with the same superscript $*=p<0.001$ in each column are significantly different from each other.

\begin{tabular}{|l|c|c|c|c|c|c|}
\hline & $\begin{array}{c}\text { No. of } \\
\text { fish }\end{array}$ & $\begin{array}{c}\text { No. of } \\
\text { cestodes }\end{array}$ & $\begin{array}{c}\text { Weight of } \\
\text { cestodes }(\mathrm{g})\end{array}$ & $\begin{array}{c}\text { Fish weight } \\
(\mathrm{g})\end{array}$ & $\begin{array}{c}\text { Fish length } \\
(\mathrm{cm})\end{array}$ & Fish c-factor \\
\hline $\begin{array}{l}\text { Fish with gravid/pregravid } \\
\text { Eubothrium sp. }\end{array}$ & 40 & $8.7 \pm 3.4^{*}$ & $6.0 \pm 0.9$ & $662 \pm 44^{*}$ & $38.9 \pm 0.8^{*}$ & $1.10 \pm 0.02^{*}$ \\
$\begin{array}{c}\text { Fish without gravid/pregravid } \\
\text { Eubothrium sp. }\end{array}$ & 50 & $21.0 \pm 4.2^{*}$ & $5.5 \pm 0.6$ & $519 \pm 34^{*}$ & $36.6 \pm 0.7^{*}$ & $1.04 \pm 0.02^{*}$ \\
\hline
\end{tabular}


Table 3. Number of Eubothrium sp., mean length $(\mathrm{cm}) \pm \mathrm{SD}$ and range $(\mathrm{cm})$ in individual salmon, and fish weight.

\begin{tabular}{|c|c|c|c|c|c|c|c|c|c|c|c|c|c|c|c|}
\hline \multicolumn{4}{|c|}{ November (3 months p.i.) } & \multicolumn{4}{|c|}{ December (4 months p.i.) } & \multicolumn{4}{|c|}{ January (5 months p.i.) } & \multicolumn{4}{|c|}{ July (11 months p.i.) } \\
\hline \multicolumn{4}{|c|}{ Cestode length } & \multicolumn{4}{|c|}{ Cestode length } & \multicolumn{4}{|c|}{ Cestode length } & \multicolumn{4}{|c|}{ Cestode length } \\
\hline No. & Mean & Range & $\begin{array}{c}\text { Fish } \\
\text { weight } \\
\text { (g) }\end{array}$ & No. & Mean & Range & $\begin{array}{c}\text { Fish } \\
\text { weight } \\
\text { (g) }\end{array}$ & No. & Mean & Range & $\begin{array}{c}\text { Fish } \\
\text { weight } \\
\text { (g) }\end{array}$ & No. & Mean & Range & $\begin{array}{c}\text { Fish } \\
\text { weight } \\
\text { (g) }\end{array}$ \\
\hline 2 & $4.0 \pm 0.8$ & $3.4-4.6$ & 205 & 0 & - & - & 230 & 0 & - & - & 320 & 1 & 2.4 & - & 384 \\
\hline 3 & $3.8 \pm 2.7$ & $0.7-5.8$ & 223 & 1 & 20.9 & - & 281 & 3 & $14.6 \pm 1.5$ & $13.0-15.9$ & 360 & 3 & $28.6 \pm 21.9$ & $5.6-49.2$ & 454 \\
\hline 3 & $4.4 \pm 2.7$ & $1.4-6.6$ & 219 & 3 & $8.8 \pm 4.7$ & $3.4-11.9$ & 246 & 4 & $12.1 \pm 9.3$ & $5.1-25.6$ & 413 & 4 & $25.0 \pm 15.3$ & $4.9-42.1$ & 578 \\
\hline 4 & $3.1 \pm 1.8$ & $1.4-4.9$ & 218 & 6 & $10.3 \pm 2.5$ & $7.6-13.3$ & 271 & 5 & $6.8 \pm 4.9$ & $3.2-15.4$ & 195 & 4 & $80.0 \pm 48.3$ & $19.1-124.4$ & 738 \\
\hline 7 & $5.6 \pm 3.3$ & $0.8-10.5$ & 284 & 8 & $2.3 \pm 1.6$ & $0.6-4.7$ & 188 & 5 & $7.8 \pm 6.6$ & $0.4-14.1$ & 365 & 6 & $25.4 \pm 20.9$ & 4.1-59.2 & 596 \\
\hline 7 & $2.4 \pm 0.9$ & $1.4-3.8$ & 262 & 12 & $6.7 \pm 4.1$ & $0.4-12.1$ & 276 & 6 & $10.1 \pm 3.8$ & $3.5-15.2$ & 367 & 7 & $26.3 \pm 18.3$ & $8.2-60.2$ & 689 \\
\hline 8 & $3.0 \pm 1.4$ & $0.7-4.9$ & 183 & 17 & $8.1 \pm 4.3$ & $2.2-16.6$ & 207 & 9 & $7.0 \pm 6.7$ & $0.8-18.8$ & 235 & 9 & $12.6 \pm 9.2$ & $0.8-21.9$ & 416 \\
\hline 14 & $1.2 \pm 0.7$ & $0.6-2.9$ & 237 & 27 & $4.5 \pm 2.7$ & $0.6-10.1$ & 199 & 17 & $5.1 \pm 3.4$ & $0.3-10.3$ & 213 & 25 & $9.5 \pm 6.4$ & $0.9-30.3$ & 369 \\
\hline 17 & $3.1 \pm 1.2$ & $0.5-4.4$ & 249 & 30 & $4.2 \pm 2.5$ & $0.2-10.6$ & 211 & 20 & $6.5 \pm 4.1$ & $1.0-17.5$ & 357 & 39 & $8.9 \pm 9.1$ & $0.5-36.9$ & 586 \\
\hline 21 & $3.5 \pm 2.2$ & $1.6-11.0$ & 173 & 56 & $2.6 \pm 1.5$ & $0.6-6.6$ & 217 & 21 & $4.8 \pm 2.1$ & $0.8-9.2$ & 302 & 59 & $4.4 \pm 4.0$ & $0.3-20.7$ & 369 \\
\hline
\end{tabular}


Table 4. Correlation between number of tapeworms and tapeworm length and between length of tapeworms and fish weight.

\begin{tabular}{|l|c|c|}
\hline & No. of worms & Fish weight \\
\hline November & $r_{\mathrm{s}}=-0.09 \mathrm{~ns}$ & $\mathrm{r}_{\mathrm{s}}=0.07 \mathrm{~ns}$ \\
December & $\mathrm{r}_{\mathrm{s}}=-0.46^{*}$ & $\mathrm{r}_{\mathrm{s}}=0.13 \mathrm{~ns}$ \\
January & $\mathrm{r}_{\mathrm{s}}=-0.29^{\times}$ & $\mathrm{r}_{\mathrm{s}}=0.29^{\times}$ \\
July & $\mathrm{r}_{\mathrm{s}}=-0.52^{*}$ & $\mathrm{r}_{\mathrm{s}}=0.35^{*}$ \\
\hline
\end{tabular}

$*=\mathrm{p}<0.001,{ }^{\times}=\mathrm{p}<0.01, \mathrm{~ns}=$ not significant

parr in hatcheries became infected with E. crassum after contact with copepods, which were the only possible intermediate hosts.

A similar but possibly separate life cycle of the marine sibling species (Eubothrium sp.) or marine race of E. crassum (cf. Kennedy 1977, 1978a, Bristow and Berland 1989) has been suggested by Akhmerov (1962) and Kennedy (1969). The present study shows that in sea water, salmon can be infected by Eubothrium sp. directly from a copepod intermediate host without a second intermediate host, which supports Akhmerov's (1962) suggestion. It is also demonstrated that $E u$ bothrium sp. is of marine origin and is able to complete its life cycle in the marine environment, producing adult tapeworms within a year after infection in accordance with Fahy (1980). However, completion of the life cycle in the marine environment does not exclude the possibility that Eubothrium sp. of marine origin is also able to complete its life cycle in fresh water. Eggs from marine Eubothrium sp. have been successfully used to infect freshwater copepods (Cyclops spp. and Eudiaptomus sp.) and eggs from fresh-water E. crassum could infect the marine copepod Acartia clausi (Hodneland and Solberg 1995). This study suggests that the two life cycles may not be completely separate. This is also supported by the fact that E. crassum has been observed to survive in sockeye salmon smolts for 7 months (Bailey et al. 1989) and in salmon smolts for at least 3 months after sea water transfer (pers. obs.). Survival of E. crassum in sea water does, however, not guarantee that it is able to produce mature eggs that could infect marine copepods and complete a marine life cycle. Kennedy (1977) found that oncospheres of freshwater E. crassum died due to osmotic stress within 48 hours in sea water. The question of whether there are one or several species of Eubothrium infecting salmonids can only be solved through further life cycleand genetic studies.

Several authors use the size of Eubothrium cestodes as a criterion for determining when the fish had been infected (Wootten 1972, Fahy 1980, Kennedy 1978b, 1983, 1996). Unsegmented Eubothrium sp. (in fresh water) was observed by Bailey et al. (1989) in sockeye salmon kept in the laboratory for 8 months without any possibility for new infections, which is in accordance with the findings of the present study. All salmon used in the present study were experimentally infected by procercoids at the same time. Still, at the end of the experiment (after 11 months), even very small $E u$ bothrium sp. $(0.3 \mathrm{~mm})$ were observed and small cestodes were present in the same fish as large mature specimens. The control fish were without any stages of Eubothrium sp., which excludes contamination of the intake water. After 11 months, only a small percentage of the Eubothrium sp. population was oviferous. Hence, interpretation of field data of Eubothrium spp. (population dynamics, growth and maturation) should be done with great caution.

The reproduction of parasites with several hosts in their life cycle is expected to depend on the abundant presence of hosts before release of eggs or larvae. Hence, Eubothrium sp. with ripe eggs should occur when intermediate hosts (copepods) are most abundant. An additional requirement for the marine Eubothrium sp. (with a development time of about 15 days in the copepod) would be the presence of a high number of the final host, $S$. salar and $S$. trutta, in the sea, if the life cycle can only be completed in the marine environment. The best period for egg release would be when the sexually mature salmon migrate to coastal waters where copepod numbers are high. At this time (May-August) the smolts of $S$. salar are also leaving the rivers (Thorpe 1988) and Eubothrium sp. would be able to infect the smolts before they migrate to sea, and the parasite would be able to continue its life cycle in the marine environ-ment. If the cestodes were shedding eggs in the open sea, where copepod intermediate hosts are not available, it would be a waste of energy for the parasite. Therefore, Eubothrium sp. should be able to time the maturation to have the most successful reproduction. The growth and maturation of pseudophyllidean cestodes are suggested to be influenced by temperature (Davydov 1978, Amin 1992) and hormone production in their host (Addis 1946, Meyer and Valleau 1967). Those salmon that are largest and show largest feeding intensity are those that reach maturity first (Kadri et al. 1996). It has been suggested that maturation of the cestode Proteocephalus jandia is related to the reproductive cycle of the fish host, i.e. governed by host hormonal level (Gil de Pertierra and Ostrowski de Núñez 1990). In the present study, fish containing gravid/pregravid Eubothrium sp. were significantly larger than fish without gravid/ pregravid cestodes. There was also a positive correlation between length of the cestodes and fish weight. Hence it is possible that the largest salmon are secreting hormones at levels which trigger some of the cestodes to grow and mature. On the other hand, it is also possible that growth and maturation of Eubothrium sp. simply reflects increased availability of nutrition in larger fish which are more metabolically active than smaller fish. 
Saksvik et al.: Infection of salmon with Eubothrium sp.
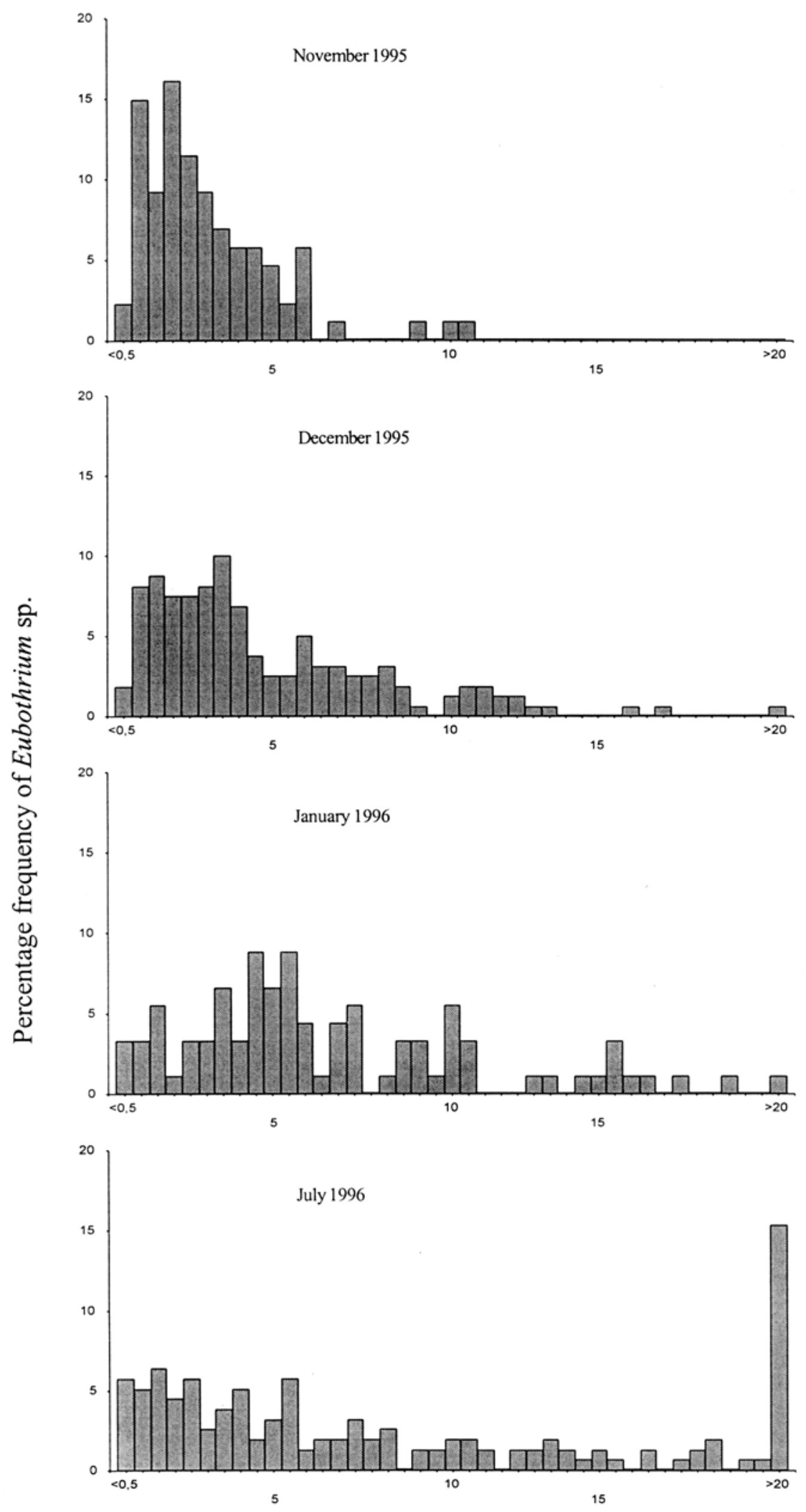

Eubothrium sp. length (cm)

Fig. 1. Length frequency distribution of Eubothrium sp. during the experimental period. 
Growth and maturation in cestodes are also believed to be influenced by the number of cestodes present in the host, i.e. crowding effect (Read 1951, Roberts 1961, Halvorsen and Andersen 1974, Hesselberg and Andreassen 1975, Davydov 1978, Sato and Kamiya 1990). Wootten (1972) found no evidence suggesting that size of E. crassum was affected by the number of cestodes. Kennedy (1996) also concluded that neither growth nor maturation of E. crassum were affected by intraspecific competition, i.e. caecal availability did not set a limit or threshold for infrapopulation density. This is in contrast with the present study where growth and maturation of Eubothrium sp. seemed to be influenced by the number of cestodes present in the salmon, suggesting that the cestodes were affected by crowding. In field studies performed by Wootten (1972) and Kennedy (1996), re-infections are possible. This makes the picture complicated and it is difficult to evaluate whether crowding does affect growth and maturation of the cestodes. The large variation in the size of $E u$ bothrium sp. within individual salmon observed in the present study could be a result of several factors influencing the development of individual cestodes. The factors most likely to be of importance are difference in response to the influence of intraspecific competition, individual variation in response to host immune response, individual variation in food uptake, or site selection. Kennedy (1996) observed a significant relationship between the size of and the position in the pyloric caeca for E. crassum, indicating that some pyloric caeca support better growth than other or that the cestodes move when they become older.

Density-dependent mortality has been reported for several cestode species (Hesselberg and Andreassen 1975, Riggs and Esch 1987, Nie and Kennedy 1992) and high initial infection by E. crassum in $S$. trutta followed by density-dependent mortality has also been observed (Kennedy 1996). It has also been suggested that loss of immature E. crassum was due to intraspecific competition (Wootten 1972). No evidence for density-dependent mortality was found in the present study. The mean intensity of Eubothrium sp. remained stable throughout the experimental period, which indicates that there was no mortality caused by intraspecific competition, host immune response or lack of essential food, even after two months of starvation (data not shown). These observations correspond with those of Smith (1973) who found no mortality of E. salvelini in Oncorhynchus nerka, and observations by Dogiel et al. (1961) and Vik (1963) who registered destrobilation of cestodes, but found the scoleces left in the intestine after starvation. Vik (1963) noted that E. crassum was able to withstand starvation for at least 4.5 months. In contrast to this, Fahy (1980) and Kennedy (1983) indicated that starvation of the host may cause mortality among the cestodes. The intensity of the cestodes in the present study was not examined until three months after infection, and it is possible that density-dependent mortality occurred during these first months as observed by Kennedy (1996) and Wootten (1972). However, since the number of cestodes intubated into the fish in the present study was relatively low, density-dependent mortality is less likely to have occurred. The variation in Eubothrium sp. intensity in the salmon used in the present study could be due to differences in regurgitating among the fish after intubating of the smolts.

Acknowledgements. Thanks to Paul Løvik for technical assistance and Professor Bjørn Berland for comments on the manuscript.

\section{REFERENCES}

ADDIS C.J. 1946: Experiments on the relation between sex hormones and the growth of tapeworms (Hymenolepis diminuta) in rats. J. Parasitol. 32: 574-580.

AKHMEROV A.Kh. 1962: On the biology of the cestode Eubothrium crassum (Bloch, 1779). Trudy GELAN 12: 58. (In Russian.)

AMIN O.M. 1992: Cestoda from lake fishes in Wisconsin: the ecology and interspecific relationships of bothriocephalid cestodes in walleye, Stizostedion vitreum. J. Helminthol. Soc. Wash. 59: 76-82.

BAILEY R.E., MARGOLIS L., WORKMAN G.D. 1989: Survival of certain naturally acquired freshwater parasites of juvenile sockeye salmon, Oncorhynchus nerka (Walbaum), in hosts held in fresh and sea water, and implications for their use as population tags. Can. J. Zool. 67: 1757-1766.

BOYCE N.P.J. 1974: Biology of Eubothrium salvelini (Cestoda: Pseudophyllidea), a parasite of juvenile sockeye salmon (Oncorhynchus nerka) of Babine Lake, British Columbia. J. Fish. Res. Board Can. 31: 1735-1742.

BRISTOW G.A., BERLAND B. 1989: Eubothrium crassum (Cestoda: Pseudophyllidea) - one species or two? Electrophoretic evidence for species status of sea-water and fresh-water forms. The 14th symposium of the Scandinavian Society for Parasitology, Helsingør, Denmark, 2-4 August 1989 (abstract).

BURT M.D.B. 1984: Problems with tense tapeworms. In: D.I. Gibson (Ed.), Technology as applied to museum collections: the collections, fixation and conservation of helminths. Syst. Parasitol. 6: 241-251.

BYKHOVSKAYA-PAVLOVSKAYA I.E. et al. 1964: Key to the Parasites of Freshwater Fish of the U.S.S.R., No 80. (Translated from Russian by Israel Program for Scientific Translation, Jerusalem, viii + 919 pp.)

DAVYDOV O.N. 1978: Growth, development and fecundity of Bothriocephalus gowkongensis (Jen, 1955) a cyprinid parasite. Hydrobiol. J. 14: 60-66.

DOGIEL V.A., PETRUSHEVSKI G.K., POLYANSKI Yu.I. 1961: Parasitology of Fishes. Oliver and Boyd, Edinburgh and London, $384 \mathrm{pp}$. 
FAHY E. 1980: Eubothrium crassum in migratory trout, Salmo trutta L., in the sea. J. Fish Biol. 16: 99-104.

GIL de PERTIERRA A.A., OSTROWSKI de NÚÑEZ M. 1990: Seasonal dynamics and maturation of the cestode Proteocephalus jandia, Woodland 1933 in the catfish Rhamdia sapia. Acta Parasitol. Pol. 35: 305-314.

HALVORSEN O., ANDERSEN K. 1974: Some effects of population density in infections of Diphyllobothrium dendriticum (Nitzsch) in golden hamster (Mesocricetus auratus Waterhouse) and common gull (Larus canus L.). Parasitology 69: 149-160.

HESSELBERG C.A., ANDREASSEN J. 1975: Some influences of population density on Hymenolepis diminuta in rats. Parasitology 71: 517-523.

HODNELAND K., SOLBERG P. 1995: Infection trials with marine Eubothrium in planktonic copepods, with aspects of procercoid development. The 4th International Symposium of Fish Parasitology, Munich, Germany 3-7 October 1995. Abstract of papers, p. 71.

HOFFMAN G.L. 1967: Parasites of North American Freshwater Fishes. University of California Press, Berkeley and Los Angeles, $486 \mathrm{pp}$.

KADRI S., MITCHELL D.F., METCALFE N.B., HUNTINGFORD F.A., THORPE J.E. 1996: Differential patterns of feeding and resource accumulation in maturing and immature Atlantic salmon, Salmo salar. Aquaculture 142: 245-257.

KANE M.B. 1966: Helminth parasites of Irish freshwater fish. Sci. Proc. R. Dublin Soc. 18: 196-199.

KENNEDY C.R. 1969: The occurrence of Eubothrium crassum (Cestoda: Pseudophyllidea) in salmon Salmo salar and trout S. trutta of the River Exe. J. Zool. (Lond.) 157: 1-9.

KENNEDY C.R. 1977: Distribution and zoogeographical characteristics of the parasite fauna of char Salvelinus alpinus in Arctic Norway, including Spitsbergen and Jan Mayen islands. Astarte 10: 49-55.

KENNEDY C.R. 1978a: The biology, specificity and habitat of the species of Eubothrium (Cestoda: Pseudophyllidea), with reference to their use as biological tags: a review. J. Fish Biol. 12: 393-410.

KENNEDY C.R. 1978b: Studies on the biology of Eubothrium salvelini and E. crassum in resident and migratory Salvelinus alpinus and Salmo trutta and in $S$. salar in North Norway and the islands of Spitsbergen and Jan Mayen. J. Fish Biol. 12: 147-162.

KENNEDY C.R. 1983: General ecology. In: C. Arme and P.W. Pappas (Eds.), Biology of the Eucestoda. Academic Press, London, pp. 27-80.

KENNEDY C.R. 1996: Establishment, survival and site selection of the cestode Eubothrium crassum in brown trout, Salmo trutta. Parasitology 112: 347-355.

KUPERMAN B.I. 1978: Features of the life cycle and biology of cestodes from Kamchatka salmon. Sov. J. Mar. Biol. 4: 763-769.

MARGOLIS L., ESCH G.W., HOLMES J.C., KURIS A.M., SCHAD G.A. 1982: The use of ecological terms in parasitology (report of an ad hoc committee of the American Society of Parasitologists). J. Parasitol. 68: 131133.
MEYER M.C., VALLEAU W.G. 1967: The effect of gonadectomy and hormone therapy in male hamsters upon egg output by the pseudophyllidean Diphyllobothrium sebago. Proc. Helminthol. Soc. Wash. 34: 41-43.

MORAND S. ROBERT F., CONNORS V.A. 1995: Complexity in parasite life cycles: population biology of cestodes in fish. J. Anim. Ecol. 64: 256-264.

MULCAHY M.F., KENNEDY C.R. 1970: Eubothrium crassum (Bloch) (Cestoda: Pseudophyllidea) in salmon parr. Ir. Nat. J. 16: 312-313.

NIE P., KENNEDY C.R. 1992: Populations of Bothriocephalus claviceps (Goeze) (Cestoda) in the European eel, Anguilla anguilla (L.), in three localities in Southwest England. J. Fish Biol. 41: 521-531.

READ C.P. 1951: The "crowding effect" in tapeworm infections. J. Parasitol. 37: 174-178.

RIGGS M.R., ESCH G.W. 1987: The suprapopulation dynamics of Bothriocephalus acheilognathi in a North Carolina cooling reservoir: abundance, dispersion and prevalence. J. Parasitol. 73: 877-892.

ROBERT F., GABRION C. 1991: Experimental approach to the specificity in first intermediate hosts of bothriocephalids (Cestoda, Pseudophyllidea) from marine fish. Acta Ecol. 12: 617-632.

ROBERTS L.S. 1961: The influence of population density on patterns and physiology of growth in Hymenolepis diminuta (Cestoda: Cyclophyllidea) in the definitive host. Exp. Parasitol. 11: 332-371.

ROSEN R. 1918: Recherches sur le développement des cestodes. 1. Le cycle évolutif des Bothriocéphales. Bull. Soc. Sci. Neuchâtel. Nat. 43: 241-300.

SATO H., KAMIYA M. 1990: Establishment, development and fecundity of Taenia crassiceps in the intestine of prednisolone-treated Mongolian gerbils and inbred mice. J. Helminthol. 64: 217-222.

SCHOLZ T. 1997: Life cycle of Bothriocephalus claviceps, a specific parasite of eels. J. Helminthol. 71: 241-248.

SMITH H.D. 1973: Observations on the cestode Eubothrium salvelini in juvenile sockeye salmon (Oncorhynchus nerka) at Babine Lake, British Columbia. J. Fish. Res. Board Can. 30: 947-964.

STØTTRUP J.G., RICHARDSON K., KIRKEGAARD E., PIHL N.J. 1986: The cultivation of Acartia tonsa Dana for use as a live food source for marine fish larvae. Aquaculture 52: 87-96.

THORPE J.E. 1988: Salmon migration. Sci. Prog. 72: 345370.

VIK R. 1963: Studies of the helminth fauna of Norway. IV. Occurrence and distribution of Eubothrium crassum (Bloch, 1779) and E. salvelini (Schrank, 1790) (Cestoda) in Norway, with notes on their life cycles. Nytt Mag. Zool. 11: 47-73.

WALNE P.R. 1970: Studies on food value of nineteen genera of algae to juvenile bivalves of the genera Ostrea, Crassostrea, Mercenaria and Mytilus. Fisheries Investigation, Series 2, vol. 26, no. 5. Ministry of Agriculture, Fisheries and Food, London, $62 \mathrm{pp}$.

WARDLE R.A., McLEOD J.A. 1952: The Zoology of Tapeworms. The University of Minnesota Press, Minneapolis, $780 \mathrm{pp}$. 
WOOTTEN R. 1972: Occurrence of Eubothrium crassum (Bloch, 1779) (Cestoda: Pseudophyllidea) in brown trout Salmo trutta L., and rainbow trout $S$. gairdneri Richardson, 1836, from Hanningfield Reservoir, Essex. J. Helminthol. 46: 327-339.

Received 25 February 1999
YAMAGUTI S. 1959: Systema Helminthum. II. The Cestodes of Vertebrates. Interscience Publisher Inc., New York, 860 pp.

Accepted 22 September 2000 